\title{
CARE AND CONVEYANCE: Buying Baladi Bread in Cairo
}

\author{
JESSICA BARNES \\ University of South Carolina \\ (D) https: / / orcid.org/0000-0001-6586-422X \\ MARIAM TAHER \\ Northwestern University \\ (iD) https:/ / orcid.org/0000-0001-6356-0265
}

The streets are already busy, despite the early hour. Minibuses jostle for space alongside bicycles, cars, and motorbikes, the fumes of idling vehicles filling the air. Honking horns punctuate a background noise of Quranic recitations playing from radios, pop music broadcasting from a store, and a babble of animated conversation. Vendors are setting up their stands for the day, peeling layers of decay off cabbages and lettuce, stacking oranges one atop another. A small hut stands by the side of the road, its window open at the front. The booth is nondescript, unmarked by any sign, with no produce on display or smells emanating from it. Within the darkened space, a woman sits behind a counter. A customer approaches. "I'll have a pound's worth, please," he says, placing several coins on the counter and handing over a plastic card. ${ }^{1}$ The woman puts the card into a small handheld machine and then reaches toward the shelves that line both sides of the booth. She starts pulling down loaves of round, flat bread, placing twenty on the bran-covered counter, and handing back the card. The customer picks up the bread, feeling the loaves and glancing briefly at each one in turn. He sets aside four loaves, which the woman exchanges for four new ones. He then moves to one side 
and spreads out his bread on the hood of a car that is parked nearby. After a few minutes, he stacks the now-cooled bread into neat piles and places it in the plastic bag he has brought with him. He departs, the bulging bag of bread in one hand, smaller bags of beans, greens, and tomatoes in the other.

This simple transaction in a Cairo neighborhood in the winter of 2015 might appear to hold little significance. Underlying the transaction, though, is a set of social, material, political, and economic relationships that reaches far beyond those of a man buying bread. The moment of card-money-bread exchange marks an interface between a government subsidy system, private business, staple food, and the millions of people who eat this food every day. The bread the customer is purchasing is a particular kind of bread, known as baladi bread, which is subsidized by the government and eaten by the majority of Egyptians (according to the government's statistics, around 85 percent) on a daily basis (see figure 1). ${ }^{2}$ The card the customer hands over is a ration card, which entitles him to five loaves of baladi bread a day for each member of his family. The money he pays covers the cost of twenty loaves at the subsidized price of 5 piasters a loaf, a tenth of the price of other kinds of bread (less than half a U.S. cent per loaf). ${ }^{3}$ The bakery he is buying from is private, but the content and size of the baladi bread it produces are regulated by the government. The way he is handling the bread, checking it for defects,

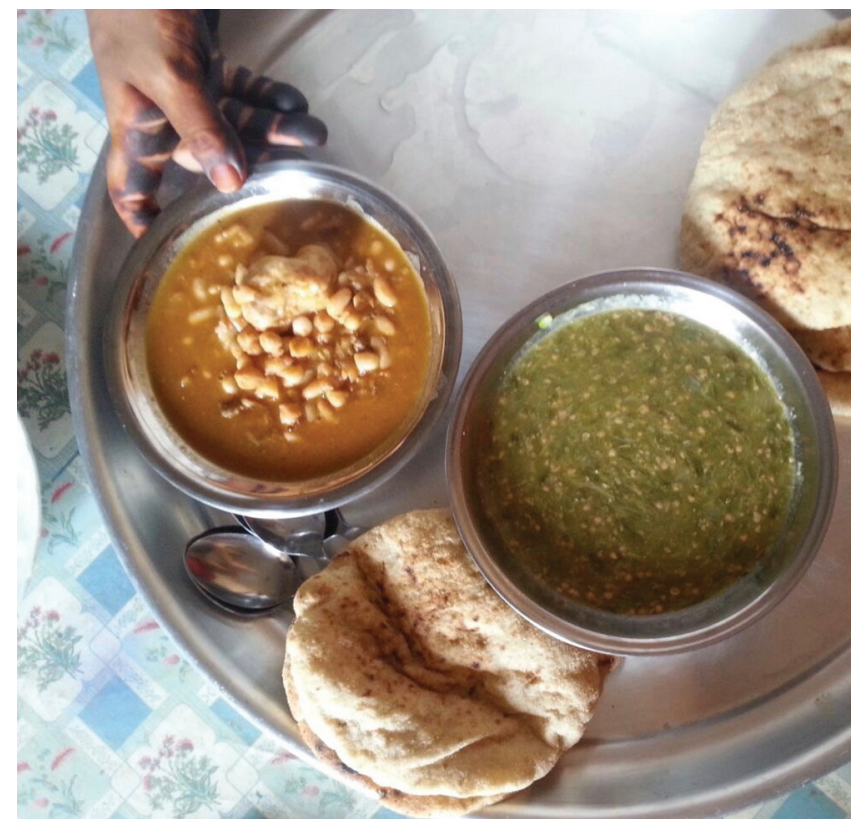

Figure 1. Baladi bread with beans and mulokhiya (jute mallow). Photo by Mariam Taher. 
laying it out to cool, and stacking it into tidy piles before placing it in his bag, ensures that his family will eat bread that is evenly cooked not burnt, well risen not collapsed, firm not soggy, round not misshapen. These interactions between the man and his bread encapsulate a mode of practice that we term casual care.

Care has become a growing topic of interest within anthropology, science and technology studies, and geography. This work has stemmed primarily from feminist scholarship, which sought to recognize the labor of care in domestic and healthcare settings (Finch and Groves 1983; Fisher and Tronto 1990). It has since expanded to explore care in a range of empirical contexts, with a central goal of elucidating particular kinds of relations between people and human and nonhuman others that often go unseen. Capacious in its meanings, care can be a mode of action, an affective stance, or an ethical value (Mol, Moser, and Pols 2010; Ticktin 2011; Barnes 2012; Buch 2015; Martin, Myers, and Viseu 2015). We focus on care as action, as a set of practices that bring together bodies, subjectivities, materials, and technologies (Mol 2008; Puig de la Bellacasa 2011).

We employ care as an analytical framework because this is what emerged from our data as a more or less consistent pattern of interactions between Cairo residents and their bread. These ways of handling bread constitute everyday forms of practice (de Certeau 1984; Bourdieu 1990), which are mediated by lines of social difference (especially class and age cohort). What makes these practices of care is people's close attunement to their bread and degree of concern for their ultimate object of consumption. While anthropologists have utilized a range of analytical approaches to think through relations between human and nonhuman others, such as assemblages (Tsing 2015) and becomings (Kirksey and Helmreich 2010), care helps convey not only a practice of engaged interaction but also the array of motivations and affective attachments expressed in practices of everyday life. People care for the bread not as an end in itself but in order to care for their families, to ensure that their families have good bread to eat. Egyptians do not, however, use the term care to describe their handling of baladi bread. That people care about baladi bread is evident in how they talk about their access to this food and what it tastes like, but nobody would talk about caring for bread (e.g., al-'ināya bi-l-'aish or al-hifāz 'ala l-'aish). ${ }^{4}$ For those who buy baladi bread daily, their behavior at the bakery is not a thing per se. It is not something that people typically reflect on (unless asked specifically about it in an interview, and even then people often appear perplexed by this line of questioning). There is no emic term to describe it. Nonetheless, how people talk about their routine of bread buying offers insight into what we regard as an embodied practice of care. 
We introduce the notion of casual care to prompt further reflection on the manner through which care can be practiced. Practices of care vary-what it means to care for something depends on the thing being cared for and the context of that care. Care can, for example, be tied to personal care histories, as when an adult cares for her mother with dementia (Taylor 2008); care can combine tenderness and clinical coolness, as when veterinarians are called on to kill animals during a disease epidemic (Law 2010); or it can engage multiply scaled life forms, as when a cheesemaker seeks to cultivate specific microbial ecologies (Paxson 2013). The addition of the modifier casual to the term care might seem oxymoronic; to act casually could be understood as acting in the absence of care. We use this word, however, to denote a particular mode of practicing care.

Casual care is not a care of calculated deliberation, such as the care of feeding patients in a nursing home (Harbers, Mol, and Stollmeyer 2002) or of checking for cracks in a canal that carries toxic waste (Ureta 2016). Rather, it is a care of routinized and quotidian acts. Tied to ingrained social norms, casual care proceeds with little apparent pause for thought. While other forms of care work may also be habitual, like cooking for a family (DeVault 1991), there is something notable about the casualness with which practices of care for baladi bread proceed. People care for baladi bread in an apparently effortless rather than studied fashion. This care is practiced by many, but not all; most of the time, but not always; sometimes meticulously, but at other times halfheartedly. Other scholars have shown how care practices are not always motivated by caring feelings (Mol, Moser, and Pols 2010; Murphy 2015). Such work has troubled assumptions about the affective domains associated with practices of care, demonstrating that one does not necessarily have to care about something to care for it. In the case of bread in Egypt, people do in fact care a great deal about it. Somewhat paradoxically, though, the manner in which they care for it is not that focused in its enactment. This troubles assumptions about what it means to care for something, demonstrating how one can practice care without being all that careful.

We explore practices of casual care for baladi bread during an important intermediary stage between purchase and consumption. While much of the work on care and food has examined practices within the domestic realm (Weismantel 1988; DeVault 1991; Carsten 1997; Janeja 2010; Kantor 2018) or around eating in a range of settings (Harbers, Mol, and Stollmeyer 2002; Lavis, Abbots, and Attala 2016), we set aside how people handle and consume bread in their homes to look at how they interact with bread at the bakery and on the street. ${ }^{5}$ This phase of conveyance is relatively unexplored in anthropological work on food. ${ }^{6}$ Yet practices 
of conveying food shape that food's taste, form, texture, and ultimately, its quality as perceived by those who consume it. Conveyance is a liminal phase during which good care can lead to bad bread being rejected and bad care can lead to good bread becoming inedible. Conveyance bridges the public and private, production and consumption, while also highlighting the fuzziness of these distinctions.

The political stakes of casual care reach far beyond the domain of the individual. Feminist scholars have shown how everyday forms of care are about much more than just looking after things, instead having deep ethico-political implications (Puig de la Bellacasa 2011, 2015). Baladi bread holds considerable political weight in Egypt. Cheap bread, which the government has subsidized since 1941, has come to be seen as an expected part of the state's social contract with its public. Although the government has made changes to the program over the years, including major reforms in 2014 in which it introduced the electronic ration card and set the five-loaf limit, the price of a loaf of baladi bread has remained the same since $1989 .^{7}$ That the government has maintained this subsidy while recently cutting a number of others, under the conditions of a 2016 International Monetary Fund loan, is telling. For many Egyptians, baladi bread constitutes the primary component of their diet. ${ }^{8}$ People expect to have enough bread to eat, and while they know that baladi bread is not necessarily the best bread on the market, they expect it to taste decent; they use the terms gamīl (beautiful) or yittäkil (edible). Baladi bread is thus one medium through which the public assesses the legitimacy of the ruling regime. When people's expectations for their staple food are not met it can be a source of political unrest, as bread riots throughout history have demonstrated (Thompson 1971; Engel 1997; Martinez 2018). In 1977, the government's attempts to raise the price of bread resulted in two days of riots around the country, with protestors attacking shops, government buildings, and police stations. The government responded with force, bringing in the army, and at least 77 people were killed and 214 wounded (Mitchell 2002, 249). In 2008, bread shortages and declining quality caused widespread anger and intermittent protests (Trego 2011). During the 2011 revolution, this staple food emerged as a central motif in the protesters' calls for "bread, freedom, and social justice" ('aish, hurriyya, 'adāla igtimāìnya).

These moments illustrate how an inadequacy in the supply of baladi bread can spark popular mobilization. Yet our research took place after the government reformed the subsidy program, in 2014, instituting changes that largely addressed problems of bread shortages and poor quality. This was a period in which there were not long lines at bakeries or prevalent complaints about the standard 
of loaves. ${ }^{9}$ The casual care we describe here, therefore, is not about predicting when the next protest might erupt or explaining the causes of previous bread riots. Rather, it is about bringing to light everyday interactions between people and their bread, which are in fact vital to producing the quality of baladi bread that Egyptians eat daily. Of course, some quality dimensions lie beyond people's control. It is government officials who regulate the nature of the flour and ingredients that go into baladi bread; it is private owners who control production conditions in the small-scale bakeries. But assuming that the baladi bread meets a certain threshold level of quality, practices of handling and selecting with care determine what it is like to consume this bread. The evidence for this lies not in what people say so much as in what they do not say, in the absence of complaints about bread being soggy, misshapen, or burnt. Without casual care, no matter how good the bread emerging from bakeries, the bread reaching people's homes would be unsatisfactory. Casual care thus helps us see that people's efforts to obtain decent, affordable bread are forged not only through moments of highly visible protest but also through actions as mundane as placing bread in a plastic bag.

Our article draws on twenty-two months of collaborative ethnographic fieldwork that we conducted in a working-class area on the outskirts of Cairo's Maadi neighborhood. This work stemmed from Jessica's book project on wheat and bread in Egypt, in which she employed Mariam, an Egyptian American, born and raised in Cairo, as a research assistant to conduct participant observation in Cairo. The goal was to provide long-term data on urban bread to complement the broader research that Jessica, who is English and has done ethnographic research in rural Egypt since 2007, did for the book during five shorter periods of fieldwork. Between 2015 and 2017, Mariam conducted observation at two bakeries, where she went to buy bread three to four times a week. She also conducted informal interviews, building on connections with several key informants in the neighborhood, whom she has known for many years. The data presented here derive primarily from Mariam's detailed field notes, yet the authors' regular discussions, both remotely and during Jessica's fieldwork visits to this Cairo neighborhood, shaped how the data collection unfolded. Similarly, while Jessica took the lead on analyzing the data and writing the article, Mariam's regular readings and contributions shaped how the essay evolved.

\section{HANDLING FOR CONVEYANCE}

Fayza walks slowly through the alleyway toward the market. It is early afternoon and Mariam is accompanying her to buy bread after a morning running 
errands together. Fayza is a widow in her sixties, who lives with her three adult children, granddaughter, and sister in a small two-bedroom apartment. For most of her life she worked in other people's homes as a cleaner, nanny, and cook, but with an injured hip and swollen legs, she now has difficulty moving around.

As with many Egyptians today, Fayza's economic well-being is unstable. She complements her meager pension with irregular short-term jobs; nobody in her household holds permanent, full-time employment. Among Fayza and her relatives, each price fluctuation in tomatoes, potatoes, or eggs is keenly felt and regularly discussed. The huge price increases since the government's currency devaluation in 2016 and fuel subsidy cuts have proven particularly challenging. Cheap, decent bread is one of the few stable things they can rely on. The family eats fresh bread every two to three days; sometimes Fayza goes to buy it, but more often her children or sister will do so on their way home from work or when buying other groceries.



Figure 2. Booth of a baladi bread bakery. Photo by Ellen Geerlings.

Mariam and Fayza arrive at the baladi bread bakery, where Fayza greets the owner, a childhood friend. The two women do not enter the bakery to make their purchase, but rather approach the booth from which this bakery, like most baladi bread bakeries, sells its bread. These booths are small kiosks on the side of the road, typically located a short distance from the building in which the baking occurs (see figure 2). The booths are staffed mostly by women, who receive the 
bread that other, usually male, workers bring them from the bakery, arranging it on the booth's shelves, and then managing the interactions with the customer, while the bakery owner moves around the premises, keeping an eye on the activities. At the booth, Fayza asks for ten loaves. The server passes her bread on a rack ('afas), a tray made of palm fronds, which she places on a wooden crate off to one side (see figure 3). Mariam touches the loaves; they are extremely hot, almost painful to touch. She and Fayza sit down. There is a woman sitting next to them, also waiting with her bread. She turns some of her loaves upside down and then back again. A boy on the other side is packing his loaves, stacking them in piles and placing them in his plastic bag. Fayza sees a woman she knows, also packing her bread nearby. She asks about her family and they talk about their news.



Figure 3. Hot bread on a rack. Photo by Mariam Taher.

Fayza is relaxed, not impatient, enjoying a few moments of rest and conversation in the shade. After about five minutes Mariam feels a loaf. The bread is 
still hot. Fayza instructs her to turn the bread around. "See the little holes in the back?" she asks. "When you turn the loaf, you are allowing the hot air to escape from here." After a few more minutes, the bread is cool enough to be packed. Mariam helps Fayza stack her loaves and place them in a plastic bag. They head back to Fayza's apartment where they unload the shopping, storing the bread in a plastic bag on the kitchen counter. Later, the family will eat the bread with vegetable stew, rice, olives, and pickled eggplant. Any leftovers Fayza will place in the freezer for future days.

This is the phase that we analyze as conveyance, a phase between purchase and consumption that involves not only transporting bread but preparing it for transport. Here, we see how working- and middle-class residents of Cairo manage the temperature, texture, and form of baladi bread, and in doing so, shape the quality of the bread they eat. The people we are talking about come from varied walks of life_-among them are laborers, policemen, housewives, government workers, teachers, and taxi drivers - yet they are united by the fact that cheap baladi bread is a central part of their daily household sustenance. While some upper-class residents do consume baladi bread (and have various practices of caring for bread inside their homes), they typically ask their domestic staff to buy bread for them. Knowing how to handle bread at the bakery and on the street, therefore, is a "gestural resource" (Elyachar 2011, 82) of the nonrich. These practices of airing, stacking, and packing constitute our first example of casual care.

\section{Airing}

Waiting is a mode of being commonly associated with Egypt's bakeries. In the past, the time that people had to wait in line when buying baladi bread was a source of great anger. Yet in the above example, Fayza and the people around her are waiting not for their bread but with their bread. They are taking five minutes or so to care for one of the bread's key material characteristics: its temperature. Immersing themselves in the bread's temporality, they are making time for it. Depending on the context, this waiting time may prove an inconvenience or, alternatively, an opportunity for social interaction (see figure 4). When Mariam asks Fayza how she feels about having to wait at the bakery, she responds, "People are eager to talk. They are under so much pressure, they use the chance to vent a bit." They vent about the challenges of their day-to-day lives while waiting with their state-subsidized bread to let off steam, performing a care that ensures that the texture of this bread is one thing they do not have to vent about. 


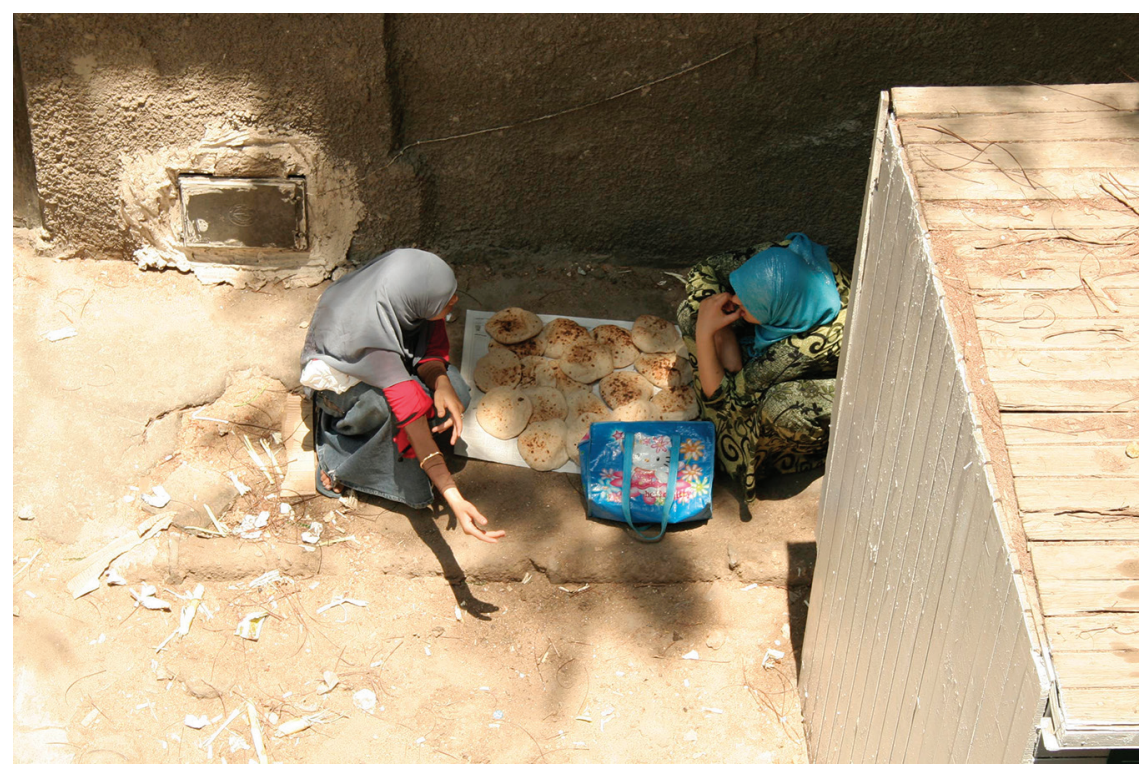

Figure 4. Airing loaves. Photo by Ellen Geerlings.

The small bakeries that produce baladi bread bake throughout the day. As the hot bread emerges from the oven, workers place it on racks, which they shuttle to the booths where the bread is sold. Sometimes they leave them in an intermediary cooling point; at other times they take them directly. The person staffing the booth keeps track of which racks came out first and how long each batch has been cooling. But the time the bread lingers on a shelving unit varies. Depending on fluctuations in demand and production, a customer may receive bread that is still hot. ${ }^{10}$

While some might think of bread's warmth as a positive characteristic, to baladi bread customers, it is not. To them, temperature is evaluated in relation to the plastic bags that they typically use to carry the bread home. ${ }^{11}$ If a customer places hot bread directly in a plastic bag, the hot air condenses on the inside of the bag, rendering the bread soggy. Egyptians talk about this in terms of the bread sweating (al-'aish biyi 'ra'). Sweaty bread is unpalatable. As Fayza commented, hot bread packed before it is cool will "stick together" (yilza' fi ba ’ụ) and "become doughy" (yib'a 'agina). Keeping bread edible hence requires management of the bread's temperature. This practice of handling with care is mediated both by the material quality of the bread (how quickly its temperature declines on exit from the oven) and of the receptacle in which it is transported (the degree to which its structure allows hot air to circulate). The material specificities of a food matter 
(Harbers, Mol, and Stollmeyer 2002); they shape the practices of care around it. The conveyor of the bread, in turn, shapes those materialities through practices of casual care.

People refer to their practices of spreading out the bread to cool before they pack it as airing (tahweya), a terminology notable for its implied sense of human agency. Instead of the bread's temperature ticking down of its own accord, as the more passive term cooling would suggest, the bread's human handlers must make it subject to the cooling work of air to bring down that temperature. They do not see this as a labor per se. Unlike past public outrage over having to wait at bakeries to buy bread_-Fayza still talks about how there used to be extremely large crowds (zahma mōt) — we have never heard anyone complain about having to wait at bakeries to air bread. While this may in part be because airing is not as time consuming as standing in line could be, it is also a different kind of waiting. ${ }^{12}$ There is a degree of uncertainty attached to waiting in a line; you do not know how quickly the line will move, or whether the bakery will run out of bread before you reach the front. Long lines often induce pushing, shouting, and fighting. For someone like Fayza, an old woman with a limp, standing in an unruly line can be both painful and unnerving. When waiting for bread to air, on the other hand, the outcome is known; you already have the bread that you will be taking home, and you are in control of where and how long you wait.

Purchasers of baladi bread are attuned to the temperature of the bread and to its need to cool sufficiently before packing. One man who has just purchased sixty loaves of bread checks with the woman in the booth before he starts packing. "Is it all aired [kulluh mithawwī]?" he asks. "Yes," she replies, "it is all well aired [mithawwì tamām, kulluh]." While this man has the expectation, or hope, that the bread be aired before he receives it, customers are used to having to manage this process themselves. They may not need to do this every time they go to a bakery. The necessity of airing depends on the bakery's production cycle, the number of customers at a particular time of day, and how long the bread has been left to rest between coming out of the oven and being handed to the customer. But it is something they are ready to do when presented with hot loaves. Around baladi bread bakeries, people temporarily commandeer small slices of public space for this airing (see figure 4). If they have received the bread in loose piles, they may lay it on a cloth or on the roof of a car. If they have purchased a whole rack of bread, they will balance the rack on whatever they can find — a rock, table, crate, or benchallowing air to circulate around the bread to cool it before they pack their loaves and return the rack to the bakery. An unspoken rule commands that bread not be 
placed directly on the ground. Should any bread fall, it is swiftly retrieved, brushed off, and packaged. The motions are quick, reflexive. Some kinds of contact are not perceived as contaminating, like the touch of a worker's hand, the squeeze by other customers, or the resting on a dust-covered bench. But contact with the ground is. The casualness of people's care is hence constrained within the limits of needing to keep the bread off the ground.

\section{Stacking and Packing}

A man stands at a bakery counter. He has just bought twenty loaves and is packing the bread into a large plastic bag. His actions are methodical. He takes several loaves into his hand, one at a time, making a little stack, and then places them on top of the growing stack in his bag. Outside another bakery, several people are doing something similar. One man has balanced his rack on two stone blocks and is crouched in front of it, stacking his bread into two large plastic bags. A short distance away, a woman is standing by a concrete flowerbed. The flowerbed has no soil or flowers but offers an elevated space on which to balance her bread. She, too, is stacking her bread in piles.

The tasks being performed here are small. People are arranging their bread, now cool, so that they can carry it home. But both the fact that they are doing it and the way in which they are doing it is telling. Thirty or forty loaves are not very heavy, but they are bulky. Unlike other food products where the packaging is incorporated in the process of production and sale, the packaging of baladi bread is left to the customer. The bread's materiality - its tendency to crease or crack if folded, and the common perception that a loaf not straight and whole is a lesser loaf - influence how it is cared for. The arrangement of the bread in the plastic bag is thus significant. On one occasion, a woman asks to purchase a plastic bag; many bakeries sell bags for those who forget to bring their own. The server asks if she wants a large bag or a small one. The woman hesitates, perhaps not knowing the sizes in question. "Take this one," says the server, passing her one. "Is it enough [hatkaffī] ?" the woman inquires. "Will it take all the bread?" The customer's concern reflects not simply whether she will physically be able to fit all her bread into the bag, but whether she can fit it in the bag in an appropriate fashion, without squashing the loaves.

Packing may take several minutes as people work with care to arrange the bread before carrying it home (see figure 5). Their practice strikes a balance between the careful and the not too careful. They do not want the bread to fold, but they handle it with the ease of an everyday good, not the weight of a delicate 




Figure 5. Stacking bread. Photo by Mariam Taher.

rarity. As Mariam helps Fayza stack her bread, their actions are habitual. Everyday routinization lies at the heart of the casualness. One man Mariam interviewed recalled the practice from his childhood: "I used to be sent out to get twenty loaves. My mother would give me a bag and I would go to the bakery." His recollection made note of the casual care he learned to perform to stack the loaves before packing them. "I would have to arrange them all first," he said. "I would lay them on top of each other." Through this practice, people help ensure that the bread arrives home round and flat, not torn (il-mit'attac), its integrity intact.

Once in the bag, the bread may require ongoing care. Watching one man carry his bread in a plastic bag as he walks down the street, we see him peer inside the bag. Some of the loaves are not straight; they are crumpled and falling into each other. The man reaches inside with a hand and tries to straighten them. There is some condensation on the inner side of the bag. He shakes the bag a little to air the loaves further.

This small act of readying the bread for conveyance resonates with other kinds of practices that anthropologists have documented in their detailed descriptions of food handling and preparation (e.g., Weiss 1996; Janeja 2010). It underscores how staple foods are about more than just fuel for the body; their taste matters. Customers care for their bread because they understand bread to be more than a source of calories. They know that for this central part of their daily suste- 
nance to be gratifying, the bread must be soft not soggy, so that they can tear off pieces to dip in a sauce; flat not crumpled, so that they can use it to make sandwiches. Caring for their own consumption and for that of their families, therefore, means not only bringing home bread but bringing home good bread.

\section{Commenting}

These practices of airing, stacking, and packing bread at the bakeries that we see as casual care constitute behaviors learned in place; they are skills honed through everyday participation in the acts of buying and eating bread. They are underpinned by a set of shared expectations about how people should interact with this bread. The ubiquity of such expectations reflects bread's deep significance as a staple food (Kanafani-Zahar 1997), whether people obtain it at market price or with a government subsidy. Shared concern for the bread's proper care elicits various forms of social interaction, from casual commentary to pointed instruction. There is a sociality tied to the bread's materiality.

When unwritten rules of conduct are violated, censuring takes place to reinforce practices of sufficient care. Criticism may be leveled at the bakery staff. Customers' complaints focus on issues that those working in the booth can control, such as the arrangement of bread on the shelves. One man waiting for his bread, for example, notices that some of the racks in the booth have two layers of bread on them. He says to the server, "Why is the bread all piled up like that? That's not OK, no [mayinfa'sh, la']! Don't put it like that, it's not good [mish kwayyis]!" His comment that the piling of bread is "not OK" implies that there is a correct way to organize the bread, tied to its need to air properly.

Other times, fellow customers are the target of criticism. While the cultural practices of care for baladi bread are patterned and habitual, they are not uniform. Most people follow them, but not everyone does, or someone might do them typically, but not always; indeed, this is one of the things that marks these practices as casual care. When someone acts with less care, however, they open themselves up to peer judgment. Take, for instance, a man who has brought newspaper with him to wrap the bread instead of a plastic bag. As he lays out newspaper on the counter in anticipation of his loaves, a woman standing next to him comments, "It's not good to place the hot bread on the newspaper, because of the writing." He looks a little confused but pulls out a glossy advertisement from within the paper and places it on top, questioningly. The woman nods in approval. In this case, the man's act of care is prompted by the woman's remonstration, and by his desire to appease a stranger and demonstrate his proficiency in appropriate conveyance. Such 
critical commentary on someone else's behavior, whether that person is known or a stranger, is quite common in Egypt. Yet the fact that people feel the need to comment, or to show their disapproval, about other people's handling of baladi bread-even when they will not themselves be affected by other people carrying their bread inappropriately — reflects the depth of social investment in the handling of baladi bread.

The impulse to reinforce social expectations around baladi bread is particularly evident in people's comments about children's handling of bread. While most children act with care as they purchase and carry bread home, not all do. Sometimes children drop their bread, several loaves toppling off a rack that a young boy carries on his head, for example, or lying on the ground around a young girl airing her bread on a bench. There is a generational dimension both to the ability to care, such as the skill of handling a large number of loaves without losing hold of any, and to the propensity to care - that is, the inclination to make the effort to maintain the bread's quality. One day, a small girl hands over half a pound and asks for ten loaves. She takes them into her arms, rather than stacking them first. As the woman in the booth piles on loaf after loaf, the girl cannot manage them all and loaves start falling to the ground. She kneels down to pick them up. A woman beside her admonishes, "Didn't you bring a bag in which to carry the bread?" Her comment reveals both her expectation that the girl, despite her young age, should handle the bread with care, and her desire to teach the child how she should act in the future.

While other ethnographic research in Cairo has shown deep gendered distinctions in how people behave in urban space (Ghannam 2011), our observations did not suggest gender differences in how people handle baladi bread. Food preparation within the home remains largely a female domain in Egypt, but men play an important role in the purchasing of food (Naguib 2015). Both men and women buy baladi bread and practice casual care as they do so. Although differences exist in how people interact with their bread - some are more casual than othersthese differences do not fall along gender lines. During airing, for instance, some people just stand beside their bread, speaking on the phone, smoking a cigarette, or chatting with a companion. Others manage the airing more actively, constantly rearranging their loaves, taking those underneath and placing them on top, turning them over so they have a chance to cool evenly. Similarly, men and women are equally subject to the criticism of others concerning their performance of care. Thus, just as scholars have long debunked the association of care with women 
alone, so too, casual care for baladi bread challenges common assumptions about the gendered relations of food provisioning in Egypt (see also Naguib 2015).

The outcome of these practices of handling with care is that the government-subsidized bread people eat in their homes three times a day is adequate in both texture and shape. While bread riots may be iconic of how citizens rally around a staple food, protest is not the only mode through which people seek to secure good subsidized bread. In caring for baladi bread as they convey it home, people are maintaining not only their families but the ongoing functioning of a state subsidy program. This subsidy program has a deep history, continued by successive regimes for more than half a century. It supports tens of millions of Egyptians daily, providing them with an affordable staple regardless of broader market conditions. It is a subsidy whose output — cheap good bread_-politicians often talk about in terms of a "red line" that cannot be crossed. Through casual care, people are helping produce a subsidized food that they value rather than revile (unlike, for instance, the "government cheese" distributed in the United States in the early 1980s, which was stigmatized for its poor nutritional quality and often moldy condition [Poppendieck 1998]). They are shaping the palatability of state-subsidized bread and thus, in a way, the palatability of the state.

\section{CHOOSING LOAVES}

Policy reports and media coverage typically portray Egypt's baladi bread as a singular object, a medium of government support to the population that is bounded by a set of government-imposed quality criteria. An international report describes, for instance, how the government's subsidy allows Egyptians "to purchase a form of flat bread called baladi at a heavily subsidized price" (McGill et al. 2015, xi, emphasis added); an article in an Egyptian newspaper proclaims to tell "the story of the subsidized loaf in eight numbers" (Saleh 2019, emphasis added). In such portrayals, consumer choice or taste preference have no role to play. Yet this bread is not baked in highly industrialized facilities in which standardization and quality checks are woven into the production process. Within the small bakeries that produce baladi bread, some steps are mechanized - such as the kneading of dough and the movement of loaves through the oven-but other steps are manual, including the measuring of ingredients, sizing of loaves, and positioning of bread on the conveyor belt that carries it through the oven. In a production setting like this, defects can emerge, such as small discolorations, inconsistencies in the dough, or burnt sections. The bread's variable material qualities open up space for critique, discernment, and selection. They generate a field of interactions at bakery 
booths as both workers and customers practice minute forms of quality control while they handle the bread.

Practices of choosing and rejecting loaves constitute our second example of casual care. Although Annemarie Mol (2008) positions patient choice as antithetical to patient care in her analysis of clinical settings, in the case of buying baladi bread, we see the power of choice to contribute to a positive care outcomenamely, a family having desirable bread to eat. That individual choices may more readily lead to good care in the case of bread than, say, of diseased bodies is perhaps not surprising. What this case demonstrates, though, is how the logic of care and the logic of choice may not, in particular circumstances of practice, stand in opposition. Mol $(2008,7)$ writes that "the logic of care is not preoccupied with our will, and with what we may opt for." With baladi bread, however, the process of opting for some loaves but not others is a form of doing care. By attaching casualness to that choice, we indicate the tacit ways in which these choices are made and conducted.

\section{Quality Control}

An old woman is standing at the booth. She seems irritated. The woman serving her has placed an entire rack of bread on the counter and the customer is choosing her loaves individually. She has already selected some, maybe five, which she has placed in a bag next to her. But she is having trouble picking out loaves satisfactory to her. She touches the loaves with her hands to assess them, feeling a few here and there, commenting that they are too dusty (mitarrab) and too dry (nāshif). Her hand movements and complaints make clear that there are no further loaves she is willing to accept. Without a word and with no visible annoyance, the woman in the booth removes the rack and presents her client with another.

This practice of checking the bread and rejecting dissatisfying loaves happens frequently. While Fayza does not closely examine her loaves on the day described above, the woman next to her removes three from the rack to exchange as she airs her bread. People assess by eye and sometimes by touch, looking for defects in color or texture, feeling for temperature, and squeezing for freshness. They do not typically smell the bread, perhaps because it does not really have a pronounced smell. Tasting is also not an option, rendering some dimensions of quality (like an occasionally sandy or metallic taste) indecipherable. But through sight and feel-the senses employed in this care (Buch 2015) — customers can detect the material characteristics commonly understood to distinguish a defective loaf from a good one: a burnt patch, flatness, hardness, discoloration, tearing, cracks on top, 
wetness, or the absence of two distinct layers. This quality assessment does not occur in a studied fashion, but rather with a quick glance or feel as customers rifle through their piles of loaves. The practice mirrors what you might see in a grocery store produce aisle or at a market stall; selection is just as important to recipients of a subsidized good as it is to customers paying market price for their food. Taste matters, including to those reliant on free or subsidized food (Trapp 2016).

Voicing their complaints, people may set aside the rejected loaves and say, "Change these [ghayyarīlī dola]." Their request is matter of fact, an everyday occurrence that does not require special justification. Other times the exchange remains wordless. One morning a woman is buying ten loaves. She takes them and, in the usual stacking-and-packing motion, puts them in the bag she has brought with her. As she does this, she sets aside two loaves, stacked one on top of the other. These loaves are more browned on top_ not burnt, but darker. She stretches her hand, touching the loaves with three fingers, and pushes them forward, nodding her head, and making eye contact with the woman in the booth. She says nothing, but her meaning is implicit; she is rejecting these loaves. The woman in the booth takes the loaves without comment and replaces them. As the customer's wordless gesture and the server's wordless response demonstrate, this is not unusual behavior. The woman in the booth does not express surprise at the customer's attention to the quality of the loaves she takes home. The people who work in bakeries typically come from similar social classes to the customers and are baladi bread consumers themselves. They share an understanding that subsidy recipients have a right to choose and that some loaves, like darker ones, may be less desirable. The rejection of bread is not a politically confrontational act; it is an assertion of an accepted right to good bread.

The bakery may discard the loaves that customers have rejected, which are sometimes referred to as "the returned" (al-rāgi $\left.{ }^{\top}\right)$. Occasionally you will see a pile of unwanted dry, burnt, cracked, or broken loaves lying marooned on racks, flies buzzing around. At other times, the bakery staff may try to pass them on to another customer. On one occasion, Mariam notes a woman setting aside three loaves as she packs her bread. They have not fully risen and have a little indentation in the top. The woman working in the booth places the loaves to the side without comment, substituting them with others. Several minutes later, she slides these same loaves into an order of twenty loaves that a boy is buying, positioning them toward the bottom as she stacks the bread for him on the counter. Anticipating that a child is less likely to pay attention to the loaves he receives, the bakery 
worker uses this as an opportunity to get rid of bread that she recognizes as less desirable. Sure enough, the boy simply takes the stacks as presented to him.

Hence people are actively engaged in selecting and maintaining the quality of the food they receive from the subsidy program to meet their needs and priorities, and this active engagement is central to their ongoing satisfaction with the subsidy. In Cairo, people are deliberate, first, in their choice of where they purchase bread (people used to be assigned bakeries, but since 2014 they have been able to use their ration cards anywhere). As one woman explained, "If you know that you can only buy a certain number of loaves, then you will choose carefully where you buy them from. If one baker produces bad bread, you won't go back there." People build relations of trust with particular bakeries and their staff, whom they feel they can rely on to give them good bread. They talk about their preferences for bread from certain neighborhoods, describing their favored bakeries with terms like niḍi $\mathrm{i}$, which means "clean" but can also be used to signify quality. "The bread of Fayda Kamel is always very nice [hilw awī] " Fayza says. "The bread in Maadi is dusty [turāb]." Sometimes they alter their movements around the city so that they can buy from a bakery whose bread they like. Fayza will often buy bread from Fayda Kamel, even though a detour to that neighborhood on public transport can take more than an hour in heavy traffic. Her sister, on the other hand, buys bread from their neighborhood, but will walk to a bakery a little further from their apartment rather than the one closest, because she says that its bread is slightly softer, a quality she appreciates because of problems with her teeth that make chewing painful. Another woman recounted how every morning her father would drive to another part of the city, park next to a bakery that he liked, take the metro downtown to work, and then buy bread on his way home from work. A conscious choice about which bakery you buy from allows for more casual choosing once there. If you know that a bakery generally produces good bread, less focused attention is required to monitor what loaves you take home.

This ability to choose, albeit casually and within limits, may itself be part of what people value about baladi bread. While to some the act of selection might seem burdensome, to Walid it is something he values. Walid is in his late forties. Originally from Fayoum Province, he currently works in Cairo as a driver. He has never married and, with no dependents to support, is economically better off than some. Having faced long periods without work, however, he remains in a position of precarity. In a world in which things are becoming more and more expensivegas, water, electricity, housing - he appreciates cheap bread. He describes baladi bread these days as "very nice" and explains how in the past when he would go to 
a baladi bread bakery and ask for a pound of bread, "they'd just give it to you." But today, he says, "You can choose, so say yes to this one, and no I don't want that one." Walid's positive perspective on the quality of baladi bread today is directly tied to his ability to choose from a variety of possible loaves, and to the care he then performs to select good ones.

\section{Favorites}

Customers are not the only ones who carry out quality control. Those working in the booths can also assess the quality of the loaves and select with care, if they wish. Sometimes they may do this in response to a request for a particular kind of bread, as when a customer asks, for instance, "Choose soft ones, please [khalīh țary w-innabī]." More commonly this selection proceeds without comment, as the person in the booth quietly selects better-looking loaves for a favored customer.

Over Mariam's repeated visits to the same bakery, this process of casual but deliberate selection on her behalf as a regular customer became evident. One day, Mariam asks for two loaves. The woman in the booth takes one and then another. The second one she picks up looks fine but is a little flat, only half risen. The woman pauses, then changes her mind. She lays down the loaf and picks up an alternate, passing Mariam two rounded loaves. In this woman's actions, we see a kind of care manifest in minute movements. Her hand hovers over several loaves before selecting the ones to give Mariam; her arm extends toward one area of a rack, then changes direction and takes from a different part; she reaches for a higher shelf, or one toward the back, even though there is a rack right next to her from which she has been selecting for other customers. She does not make a big deal of it, but it is clear from the movement of the hand and the scanning of her eyes that she is being selective. Accustomed to handling bread and assessing quality, her movements are quick, but this does not preclude accuracy. The loaves she presents to Mariam are often warm but not hot, slightly soft, and clearly fresh. This form of casual care resembles the care of handling and choosing bread; in this case, though, the agent of the care is the server, not the customer.

Not everyone receives such special treatment. Indeed, the woman working in the booth who slips the inferior loaves into the boy's stack is not caring for his bread. When Mariam has purchased bread at other bakeries that she visits less regularly, she has at times been struck by the lack of care displayed when a server does not glance to check or touch to feel each loaf, acting as though all loaves were equal and dumping them on the counter without making eye contact. In caring 
for the bread through selecting good loaves, however, the person working in a bakery can care for a favored customer. By drawing on a sensorial engagement with the bread and an ability to read the bread through sight and touch, the server can cultivate a relationship of trust with a regular client, mediating the quality of subsidized bread that they get to eat. Facilitating this casual care for the bread is a mutual understanding between the server and the customer that some loaves are better than others and that specific material characteristics distinguish good bread from bad.

\section{CASUAL CARE}

The Egyptian bread riots of 1977 loom large in the country's political imagination and are frequently recalled in politicians' speeches and newspaper articles. The refrain of the 2011 revolution - bread, freedom, and social justice-also reverberates widely, underscoring the political centrality of bread in general, as a symbol of livelihoods, and of baladi bread specifically. These moments of drama tell us about how a staple food can become a flashpoint for protest, a means through which people signal their dissatisfaction with the state. But they tell us little about the day-to-day functioning of a subsidized bread program, or about the conditions that produce a general level of satisfaction with the availability and quality of baladi bread and the absence of protest.

Attention to casual care helps us recognize the importance of social and material relations between people and bread, and among people through bread, that transpire outside these times of crisis. It reveals the continuous ways in which people care for themselves and for their families through their everyday acts of airing, stacking, packing, choosing, and returning loaves. While the efficacy of this care is contingent on the quality of government-regulated ingredients and bakeries' production processes, so too, the quality of bread that people eat is contingent on casual care. The impact of this care during conveyance is evident in what goes unsaid. People do not complain about baladi bread being soggy or squashed because they handle it to ensure that this is not the case. They do not complain about it being unevenly cooked, burnt, or poorly risen because they select it to ensure that they do not bring home such loaves. Casual care is thus one reason why people's expectations for good bread are being met; it shapes their experience of eating baladi bread. In caring for their bread, therefore, people are also, albeit unwittingly, caring for the government, ensuring the palatability of this central item of state support. 
More broadly, this essay opens up spaces of everyday practice that we might productively approach as care. As the literature on care has expanded from contexts readily associated with looking after people-hospitals, homes, clinics, assisted-living facilities - into domains as diverse as wetlands (Scaramelli 2018), urban streets (Kullman 2014), and copper mines (Ureta 2016), it raises the question of how far we can go in what we see and write about as care. Care helps elucidate particular kinds of relationships and forms of engagement between people and others, and their material, affective, and embodied outcomes. But in using a term so infused with ethical and moral connotations, we run the risk of making assumptions about how that care unfolds. Casual care represents a mode of practice that is intentional but also habitual, deliberate but also perfunctory. The purpose of this designation is not to undermine the import of those care practices; such care may hold political stakes that the casualness of its performance belies. Rather, the concept of casual care is designed to challenge the association of care with a type of highly focused activity. The analytical purchase of this concept is that it sheds light not only on the form of action, what it means to care for something, but on the way in which those actions are practiced, what it means to be casual. As we acknowledge some of the different ways in which people may perform care, we trouble the dichotomy between being careful and careless, showing how one may care, but care casually.

\begin{abstract}
The Egyptian government has long subsidized bread as part of its program of social support. Most Egyptians eat this subsidized bread, known as baladi bread, daily. We examine everyday practices of handling baladi bread as casual care. Scholarship on care has drawn attention to the multiple ways in which care can be practiced around a range of human and nonhuman others. Casual care signals a mode of practice that constitutes care but that is not necessarily performed by its practitioners as such. It is intentional but also habitual, deliberate but also perfunctory. We look at people's casual care for baladi bread during the understudied phase of conveyance, between the moment of purchase and arrival at home. Practices of handling and selecting bread help produce the quality of the baladi bread that people are eating. While past bread riots have underscored the political salience of this bread, casual care elucidates what goes on between these moments of crisis, revealing the role of people's day-today actions in producing a general level of satisfaction with subsidized bread. This analysis draws theoretical attention to how care is practiced, opening up space for thinking about kinds of care that are not all that careful in their enactment. [care; bread; food; Egypt; everyday]
\end{abstract}




$$
\begin{aligned}
& \text { منذ فترة طويلة يثل دعم الحكومة المصرية للخبز جزءا أساسيا من برنامج الدعم الاجتهاعي. يأكل }
\end{aligned}
$$



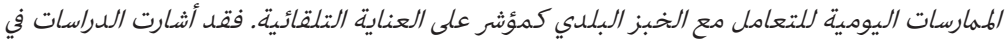

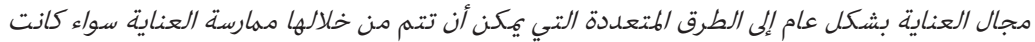

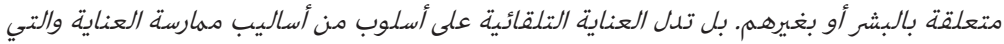

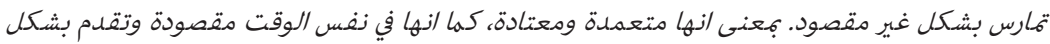

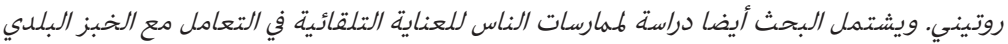

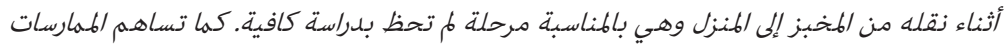

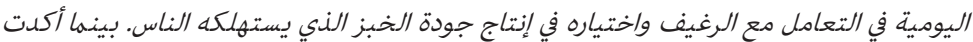

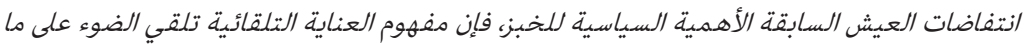

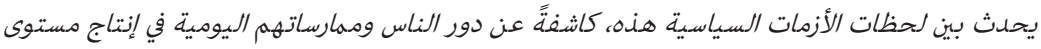

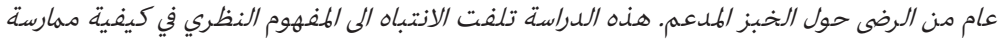

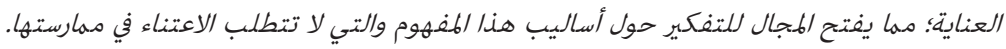

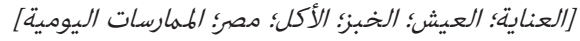

\section{NOTES}

Acknowledgments This article benefited from comments by the following people at various stages of its development: Hayden Kantor, Sophia Stamatopolou-Robbins, Andrew Mathews, David Kneas, Caterina Scaramelli, Kali Rubaii, Tessa Farmer, Simone Popperl, and Ashley Carse. We are also grateful to the anonymous reviewers and members of the Cultural Anthropology editorial collective, particularly Heather Paxson, for their detailed and constructive engagement with the essay. Funding for the research and writing of this article was provided by the American Council of Learned Societies, the George A. and Eliza Gardner Howard Foundation, and the University of South Carolina.

1. The currency in Egypt is the Egyptian pound (EGP). There are 100 piasters in a pound. At the time of writing, 1 EGP was equal to US\$0.06.

2. This figure comes from Abdallah and Al-Shawarby (2017, 125). The word baladī means local, traditional, rural, or "my country." Baladi bread is also sometimes referred to as "subsidized bread" (al-'aish al-muda'am) or "the bread of the Ministry of Supply" ('aish al-tamwin), after the ministry that manages the subsidy program. While people occasionally refer to other kinds of bread, which are similar to the subsidized bread or identified as being "traditional," as baladi bread, in this article we reserve the term for government-subsidized bread.

3. People without ration cards can still buy baladi bread; they just have to pay around fifty piasters a loaf, which is closer to the cost of production.

4. Our transliterations throughout the article aim to reflect the phonology of colloquial Cairene Arabic.

5. There are a number of practices of caring for bread within the home, such as not throwing away bread and managing freshness through freezing and heating, which Jessica explores in her current book project, Precarious Staples: Wheat, Bread, and the Taste of Security in Egypt.

6. There is only passing reference to conveyance, for instance, in Sidney W. Mintz and Christine M. Du Bois's (2002) review of the anthropological literature on food. While a number of studies of global food commodities have shed light on conveyance and handling between sites of production and points of sale (e.g., Bestor 2004; Freidberg 2004; Fischer and Benson 2006), our interest lies in conveyance between the moment of sale and entry into the home. 
7. The 2014 reforms were designed to address shortages due to limited supply (linked to bakers siphoning off subsidized flour to the black market) and excess demand (linked to people buying large numbers of loaves and sometimes feeding them to livestock), as well as poor quality (linked to the absence of competition between bakeries) (Kamal 2015).

8. According to government statistics, for 60 percent of households, baladi bread constitutes the main food item (Hassan-Wassef 2012, 13).

9. In a 2016 survey of baladi bread consumers, 91 percent responded that the bread quality had improved since the 2014 reforms (Abdalla and Al-Shawarby 2017, 129).

10. Many nonsubsidized breads for sale in Cairo, by contrast, are sold prepackaged, obviating the need for customer care.

11. Although some people use other receptacles like cardboard boxes or string bags, or borrow a rack from the bakery to transport their bread home, plastic bags are the most common medium of conveyance, given their convenience for carrying multiple items and their widespread availability.

12. In a survey of 1,784 bakeries conducted before the reforms, Tim Coelli $(2010,30)$ found waiting times of up to 100 minutes, with an average of 12.4 minutes.

\section{REFERENCES}

Abdalla, Moustafa, and Sherine Al-Shawarby

2017 "The Tamween Food Subsidy System in Egypt: Evolution and Recent Implementation Reforms." In The 1.5 Billion People Question: Food, Vouchers, or Cash Transfers? edited by Harold Alderman, Ugo Gentilini, and Ruslan Yemstov, 107-150. Washington, D.C.: The World Bank.

Barnes, Marian

2012 Care in Everyday Life: An Ethic of Care in Practice. Chicago: Policy Press.

Bestor, Theodore C.

2004 Tsukiji: The Fish Market at the Center of the World. Berkeley: University of California Press.

Bourdieu, Pierre

1990 The Logic of Practice. Translated by Richard Nice. Stanford, Calif.: Stanford University Press. Originally published in 1980.

Buch, Elana D.

2015 "Anthropology of Aging and Care." Annual Review of Anthropology 44: 277-93. https://doi.org/10.1146/annurev-anthro-102214-014254.

Carsten, Janet

1997 The Heat of the Hearth: The Process of Kinship in a Malay Fishing Community. New York: Oxford University Press.

Coelli, Tim

2010 "The Cost Efficiency in the Production and Distribution of Subsidized Bread in Egypt.” Report. Washington, DC: World Bank.

de Certeau, Michel

1984 The Practice of Everyday Life. Translated by Steven Rendall. Berkeley: University of California Press. Originally published in 1980.

DeVault, Marjorie L.

1991 Feeding the Family: The Social Organization of Caring as Gendered Work. Chicago: Elyachar, Julia University of Chicago Press.

2011 "The Political Economy of Movement and Gesture in Cairo." Journal of the Royal Anthropological Institute 17, no. 1: 82-99. https://doi.org/10.1111/j.14679655.2010.01670.x.

Engel, Barbara Alpern

1997 “Not by Bread Alone: Subsistence Riots in Russia during World War One." Journal of Modern History 69, no. 4: 696-721. https://doi.org/10.1086/245591. 
Finch, Janet, and Dulcie Groves, eds.

1983 A Labor of Love: Women and Caring. Boston: Routledge and Kegan Paul.

Fischer, Edward, and Peter Benson

2006 Broccoli and Desire: Global Connections and Maya Struggles in Postwar Guatemala. Palo Alto, Calif.: Stanford University Press.

Fisher, Berenice, and Joan Tronto

1990 "Toward a Feminist Theory of Caring." In Circles of Care: Work and Identity in Women's Lives, edited by Emily K. Abel and Margaret K. Nelson, 35-62. Albany: State University of New York Press.

Freidberg, Susanne

2004 French Beans and Food Scares: Culture and Commerce in an Anxious Age. New York: Oxford University Press.

Ghannam, Farha

2011 "Mobility, Liminality, and Embodiment in Urban Egypt." American Ethnologist 38, no. 4: 790-800. https://doi.org/10.1111/j.1548-1425.2011.01337.x.

Harbers, Hans, Annemarie Mol, and Alice Stollmeyer

2002 "Food Matters: Arguments for an Ethnography of Daily Care." Theory, Culture, and Society 19, nos. 5-6: 207-226. https://doi.org/10.1177/026327602761899228.

Hassan-Wassef, Habiba

2012 "The Politics of Bread in Egypt." CIHEAM Watch Letter, no. 23: 11-14. https:// www.ciheam.org/en/publications/watch_letter/details?pub=WL_23\&id=24.

Janeja, Manpreet K.

2010 Transactions in Taste: The Collaborative Lives of Everyday Bengali Food. New Delhi: Routledge.

Kamal, Oday

2015 Half-Baked, the Other Side of Egypt's Baladi Bread Subsidy: A Study of the Market Intermediaries and Middlemen in the System. Barcelona: CIDOB. https://www.cidob. org/en/publications/publication_series/monographs/monographs/half_baked_ the_other_side_of_egypt_s_baladi_bread_subsidy.

Kanafani-Zahar, Aida

1997 “'Whoever eats you is no longer hungry, whoever sees you becomes humble': Bread and Identity in Lebanon." Food and Foodways 7, no. 1: 45-71. https://doi.org/10.10 80/07409710.1997.9962051.

Kantor, Hayden S.

2018 "Building Beyond the Bypass Road: Urban Migration, Ritual Eating, and the Fate of the Joint Family in Patna, India." American Anthropologist 120, no. 2: 212-23. https://doi.org/10.1111/aman.12972.

Kirksey, Eben, and Stefan Helmreich

2010 "The Emergence of Multispecies Ethnography." Cultural Anthropology 25, no. 4: 545-76. https://doi.org/10.1111/j.1548-1360.2010.01069.x.

Kullman, Kim

2014 "Children, Urban Care, and Everyday Pavements." Environment and Planning A 46, no. 12: 2864-80. https://doi.org/10.1068/a46260.

Lavis, Anna, Emma-Jayne Abbots, and Luci Attala

2016 "Introduction: Reflecting on the Embodied Intersections of Eating and Caring." In Careful Eating: Bodies, Food and Care, edited by Emma-Jayne Abbots, Anna Lavis, and Luci Attala, 1-21. Burlington, Vt.: Ashgate.

Law, John

2010 "Care and Killing: Tensions in Veterinary Practice." In Care in Practice: On Tinkering in Clinics, Homes and Farms, edited by Annemarie Mol, Ingunn Moser, and Jeannette Pols, 57-72. Bielefeld, Germany: Transcript Verlag.

Martin, Aryn, Natasha Myers, and Ana Viseu

2015 "The Politics of Care in Technoscience." Social Studies of Science 45, no. 5: 625-41. https://doi.org/10.1177/0306312715602073. 
Martinez, José Ciro

2018 "Leavened Apprehensions: Bread Subsidies and Moral Economies in Hashemite Jordan.” International Journal of Middle East Studies 50, no. 2: 173-93. https://doi. org/10.1017/S0020743818000016.

McGill, Julian, Dmitry Prikhodko, Boris Sterk, and Peter Talks

2015 "Egypt: Wheat Sector Review." Country Highlights report. Rome: Food and Agriculture Organization of the United Nations.

Mintz, Sidney W., and Christine M. Du Bois

2002 "The Anthropology of Food and Eating." Annual Review of Anthropology 31: 99-119. https://doi.org/10.1146/annurev.anthro.32.032702.131011.

Mitchell, Timothy

2002 The Rule of Experts: Egypt, Techno-Politics, Modernity. Berkeley: University of California Press.

Mol, Annemarie

2008 The Logic of Care: Health and the Problem of Patient Choice. New York: Routledge.

Mol, Annemarie, Ingunn Moser, and Jeannette Pols

2010 "Care: Putting Practice into Theory." In Care in Practice: On Tinkering in Clinics, Homes, and Farms, edited by Annemarie Mol, Ingunn Moser, and Jeannette Pols, 7-26. Bielefeld, Germany: Transcript Verlag.

Murphy, Michelle

2015 "Unsettling Care: Troubling Transnational Itineraries of Care in Feminist Health Practices." Social Studies of Science 45, no. 5: 717-37. https://doi. org/10.1177/0306312715589136.

Naguib, Nefissa

2015 Nurturing Masculinities: Men, Food, and Family in Contemporary Egypt. Austin: University of Texas Press.

Paxson, Heather

2013 The Life of Cheese: Crafting Food and Value in America. Berkeley: University of California Press.

Poppendieck, Janet

1998 Sweet Charity? Emergency Food and the End of Entitlement. New York: Viking.

Puig de la Bellacasa, Maria

2011 "Matters of Care in Technoscience: Assembling Neglected Things." Social Studies of Science 41, no. 1: 85-106. https://doi.org/10.1177/0306312710380301.

2015 "Making Time for Soil: Technoscientific Futurity and the Pace of Care." Social Studies of Science 45, no. 5: 691-716. https://doi.org/10.1177/0306312715599851.

Saleh, Amin

2019 "Infogrāf: Qisssat raghīf al-khobz al-muda'am fi 8 arqām" [Infographic: The Story of Scaramelli, Caterina the Subsidized Loaf in Eight Numbers]. Al-Youm Al-Saba', January 18.

2018 “'The wetland is disappearing': Conservation and Care on Turkey's Kizilirmak Delta." International Journal of Middle East Studies 50, no. 3: 405-425. https://doi.

Taylor, Janelle S. org/10.1017/S0020743818000788.

2008 "On Recognition, Caring, and Dementia." Medical Anthropology Quarterly 22, no. 4:

Thompson, E. P. 313-35. https://doi.org/10.1111/j.1548-1387.2008.00036.x.

1971 "The Moral Economy of the English Crowd in the Eighteenth Century." Past and Ticktin, Miriam Present 50, no. 1: 76-136. https://doi.org/10.1093/past/50.1.76.

2011 Casualties of Care: Immigrants and the Politics of Humanitarianism in France. Berkeley:

Trapp, Micah M. University of California Press.

2016 "You-Will-Kill-Me-Beans: Taste and the Politics of Necessity in Humanitarian Aid.” Cultural Anthropology 31, no. 3: 412-37. https://doi.org/10.14506/ca31.3.08. 
Trego, Rachel

2011 "The Functioning of the Egyptian Food-Subsidy System During Food-Price Shocks." Development in Practice 21, nos. 4-5: 666-78. https://doi.org/10.1080/09 614524.2011 .562879 .

Tsing, Anna Lowenhaupt

2015 The Mushroom at the End of the World: On the Possibility of Life in Capitalist Ruins. Princeton, N.J.: Princeton University Press.

Ureta, Sebastian

2016 "Caring for Waste: Handling Tailings in a Chilean Copper Mine." Environment and Planning A 48, no. 8: 1532-48. https://doi.org/10.1177/0308518X16645103.

Weismantel, Mary J.

1988 Food, Gender, and Poverty in the Ecuadorian Andes. Philadelphia: University of Pennsylvania Press.

Weiss, Brad

1996 The Making and Unmaking of the Haya Lived World: Consumption, Commoditization, and Everyday Practice. Durham, N.C.: Duke University Press. 